\title{
Performance of Winter Wheat Varieties in White Clover Living Mulch
}

\author{
Jürg Hiltbrunner ${ }^{1, *}$ and Markus Liedgens ${ }^{2}$ \\ ${ }^{1}$ Federal Department of Economic Affairs DEA, Agroscope Reckenholz- \\ Tänikon Research Station ART, Reckenholzstr. 191, CH-8046 Zurich, \\ Switzerland. 'Institute of Plant Sciences, Swiss Federal Institute of \\ Technology (ETH), Universitätstr. 2, CH-8092 Zurich, Switzerland
}

\section{ABSTRACT}

The choice of variety for agricultural systems with multiple crops may differ from the one used in sole crop because of the changes in environmental conditions brought about by interspecific plant competition. Information about varietal performance under living mulch conditions as well as the suitability of the results of the official variety testing, conducted under conventional cropping conditions, for such systems is lacking for small grain cereals such as winter wheat (Triticum aestivum L.). In the current study, nine different winter wheat varieties were established in an existing living mulch of white clover (Trifolium repens L.) in three trials in the Swiss Midlands in the years 2003 and 2004. The winter wheat was directly sown in widely spaced rows $(0.375$ $\mathrm{m})$ at a density of 450 viable grains $\mathrm{m}^{-2}$. Grain yield varied between 1.83 and $4.11 \mathrm{Mg} \mathrm{ha}^{-1}$. Plant height was correlated $(r=0.92, p<0.001)$ with the grain yield, suggesting that varieties with long shoots may have an advantage because of the more intense shading of the white clover plants. However, the best yielding varieties were also those with the most intense tillering. Recorded values of grain quality traits (grain weight, test weight and protein content) for the tested varieties were analogous under the living mulch conditions of the current trials to those obtained in the official variety testing. This analogy was not observed for the grain yield, except for one trial, where the competitive strength of the white clover was reduced by mechanical interference prior to the seeding of the wheat, which positively affected tillering and hence grain yield. Thus, the use of better yielding varieties of winter wheat in living mulches is at the cost of decreased grain quality. The combination of yield and quality goals in living mulch systems will rather depend on the minimization of the competition of the cover crop on the wheat plants than on the variety choice following recommendations based on trials conducted under conventional cropping conditions. 


\section{INTRODUCTION}

The practice of living mulch systems, which is a kind of mixed cropping where one crop (main crop) produces the yield and the other covers the soil (cover crop), is an environmentally sound way to farm the land. Compared with conventional cropping systems with ploughing and monocultures, living mulch systems have several agronomic advantages, such as efficient erosion control, weed suppression, improved soil structure, and self-regulation of pests and diseases (Feil \& Liedgens, 2001). Until now, living mulches have mainly been used in perennial crops (Hartwig \& Ammon, 2002) where competition from light and water is largely avoided due to the significant differences in the dimensions of the aerial and below-ground parts allowing the perennial main crop to maintain an advantage over the cover crops. In spite of the environmental benefits and the possibility of improving the quality of the main crop (Brandsæter et al., 1998; Thorsted et al., 2006a), living mulches are hardly used in annual crops, mainly because of the risk of lower yields compared with traditional cropping systems. This yield reduction is likely caused by the competition for light, water and nutrients between the cover and main crop, which is, at least to a certain degree, unavoidable (Thorsted et al., 2006b). For example, low grain yields of winter wheat were typically associated with low ear densities and attributed to either poor germination or weak plants resulting from the competition exerted by the cover crops (Bergkvist, 2003a; Neumann, 2005; Hiltbrunner et al., 2007a).

The key to increase the main crop's relative use of the available resources is to reduce the cover crop's competitiveness. This can be achieved by using less competitive cover crop genotypes (Bergkvist, 2003a; Hiltbrunner et al., 2007a) or by the selective weakening of the cover crop, for example by tilling strips in which the main crop is established (Thorsted et al., 2006b). However, with both strategies the risk of less effective weed suppression is increased when compared with living mulch systems with competitive cover crops and direct seeding.

An alternative to the approach of reducing the cover crop's competitiveness is to increase the main crop's competitiveness. Hiltbrunner et al. (2007b) showed that doubling the seeding density for directly drilled winter wheat from 300 to 600 kernels $\mathrm{m}^{-2}$ significantly increased the grain yield by about $0.6 \mathrm{Mg} \mathrm{ha}^{-1}$, on the average of three studied environments.

Furthermore, choosing the right variety for the main crop may contribute towards the development of a living mulch system with white clover and winter wheat with a satisfactory grain yield. However, research is lacking in this regard for living mulch systems, but the importance of using the appropriate main crop variety in mixed cropping systems has been shown in the review of Davis \& Woolley (1993), which focuses on more general intercropping systems. 
Tillering and subsequent tiller formation are crucial for the canopy development and consequently determine to a large extent the grain yield. The seeding date and seeding density, as well as the quantity of fertilizer can influence the number of tillers. Light and temperature as environmental factors also influence tiller formation (Friend, 1965; Vielmeyer \& Weissert, 1990). Since light competition exists in living mulch systems (Thorsted et al., 2006b), the tillering of less competitive varieties of winter wheat may be more affected than that of more competitive ones. Consequently, this may also influence the grain yield and other yield determining parameters, resulting in differences when compared with wheat grown with no competition (official variety testing).

Each year in the official variety testing in Switzerland, new wheat varieties are compared at different sites with varieties already used by farmers to evaluate their potential with respect to grain yield, quality and disease tolerance. These tests are conducted under conditions of no weed competition and with conventional tillage.

In the present experiment different winter wheat varieties were cropped in a white clover (Trifolium repens L.) living mulch system. The objective was to investigate the difference among the selected set of varieties under a living mulch setting in terms of the yield, yield components and quality parameters. Additionally, the experimental results were related to those of the official Swiss variety testing procedure (Menzi et al., 2003). The goal is to infer whether a different variety testing procedure may be necessary for alternative cropping systems such as living mulches.

\section{MATERIAL AND METHODS}

\section{Experimental sites}

The study was conducted on two sites in the Swiss Midlands near Zurich (site 1, Reckenholz: $47^{\circ} 26^{\prime} 27^{\prime \prime} \mathrm{N}, 8^{\circ} 31^{\prime} 45^{\prime \prime} \mathrm{E}, 480 \mathrm{~m}$ above sea level) and near Winterthur (site 2, Strickhof: 47²6'50"N, 841'10"E, $547 \mathrm{~m}$ above sea level). Three identical trials were carried out in the seasons of 2003/2004 (R04 at site 1 and S04 at site 2) and 2004/2005 (R05 at site 1). In accordance with the FAO scheme, the soils were classified as Cambisols at both sites with a $\mathrm{pH}$ of 6.8 (site 1) and 7.7 (site 2). The soil organic matter content was $2.6 \%$ and $3 \%$ at sites 1 and 2, respectively. Averaged over the past 25 years, the annual mean temperature and precipitation were $9.2^{\circ} \mathrm{C}$ and $1040 \mathrm{~mm}$ (site 1) and $8.8^{\circ} \mathrm{C}$ and $1130 \mathrm{~mm}$ (site 2). Both experimental sites have been farmed according to the Swiss guidelines of organic farming (Bio Suisse, 2005) since 2002 (site 1) and 1994 (site 2). The previous crops were spring oats (Avena sativa L.) at site 1 and faba bean (Vicia faba L.) at site 2. 


\section{Establishment of treatments and crop management}

Small-leaved white clover (Trifolium repens L. cv. Barbian, Barenbrug, The Netherlands) was sown as a cover crop at both sites. The sowing was carried out using regular farm equipment with rates of $15 \mathrm{~kg} \mathrm{ha}^{-1}$ and a target seeding depth of $0.01 \mathrm{~m}$ at the end of July 2002 at site 1 and at the end of August 2003 at site 2 . At site $2,2 \mathrm{~kg}$ of white clover seeds were substituted by seeds of the non hardy berseem clover (Trifolium alexandrinum L. cv. Sacromonte) with the aim of achieving a partial regulation of the living mulch through frost killing a fraction of the clover plants during the winter. However, due to the mild winter, plants of the berseem clover unexpectedly survived the winter. At site 1 between the sowing of the white clover and the sowing of the winter wheat the white clover was used as cattle feed (silage). No fertilizer was applied prior to the establishment of the main crop in the fall, except in 2004 where $25 \mathrm{t} \mathrm{ha}^{-1}$ of compost (dry matter) was spread over site 1 in order to maintain long-term fertility of the parcel, which is farmed without livestock. Before sowing the winter wheat, the white clover was cut with a power mower to a target height of $0.05 \mathrm{~m}$ and the cut material was removed from the field.

Nine different varieties of winter wheat (Triticum aestivum L. cvs. Arina, Asketis, Ataro, Habicht, Levis, Pegassos, Segor, Titlis, Zinal) were selected so that at least two varieties represented one of the four existing quality categories (TOP, I, II, III) defined for bread making quality in Switzerland (Table 1). The classification is based on tests conducted in the laboratory (e.g. protein content, falling number) together with baking tests (e.g. bread volume, distribution of the pores in the crumb). Classes TOP and III represent the best and lowest quality for bread making, respectively. Variety Ataro was selected under organic farming conditions and is recommended for organic farms only. The varieties were seeded at a density of 450 kernels $\mathrm{m}^{-2}$ into the living mulches on 13 October, 2003 and 14 October, 2004 at site 1 and 13 October, 2003 at site 2 (Table 2). The seeding densities were adjusted according to germination tests. A modified Direttissima 250 no-tillage seeder (Gaspardo, Pordenone, Italy) with single disc openers and a row space of $0.3750 \mathrm{~m}$ was used.

The white clover in between the wheat rows was cut three times during the main crop season to reduce competition between the cover and main crop (Table 2). Based on the first two trials (R04 and S04) and to ensure better conditions for the juvenile phase of winter wheat, an additional cut of the white clover at ground level in the seeding row was performed using a rowmulcher prior to crop seeding in the R05.

During the wheat's growing season, Biorga (Hauert HBG Dünger AG, Grossaffoltern, Switzerland) and farmyard manure were applied at sites 1 and 2 , respectively, with a target of $60 \mathrm{~kg} \mathrm{ha}^{-1}$ of nitrogen $(\mathrm{N})$ (Table 3). The 
total amount of fertilizer was divided into two applications; one during wheat tillering and the other during shoot elongation (Table 2).

\section{Sampling and analysis of plants}

The plant, tiller and ear densities were counted before tillering $(\mathrm{BBCH}$ growth stage 20 (Lancashire et al., 1991)), at the end of tillering (BBCH 29) and after anthesis (BBCH 80), respectively, according to the $\mathrm{BBCH}$ scale on subplots $\left(1.5 \mathrm{~m}^{2}\right.$ at $\mathrm{R} 04$ and $\mathrm{S} 04 ; 0.75 \mathrm{~m}^{2}$ at R05) marked at the beginning of the sampling. The yield components, ear density, number of grains per ear, and the harvest index were determined from sub-plots of $0.5 \mathrm{~m}^{2}$ (R05) and 1.0 $\mathrm{m}^{2}$ (R04) cut just before harvest. In S04 no such sub-samples were harvested due to a hailstorm during the grain filling process, which greatly influenced the yield and quality parameters. Grain yield was determined from plots (12 $\mathrm{m}^{2}$ ) harvested with a combine (Wintersteiger, Ried, Austria) at S04 (3 August 2004) and R05 (27 July 2005). Due to lodging of the winter wheat at R04, the plots $\left(10 \mathrm{~m}^{2}\right)$ were harvested by hand (3 August 2004) and threshed in the laboratory (Saatmeister, Kurt Pelz, Bad Godesberg, Germany). The grains were dried and the values of grain yield were adjusted to a moisture content of $15 \%$.

Grain yields, grain protein concentration, and test weight (the weight of 100 litres of grain) were evaluated at maturity from the samples harvested with the combine. Number of grains per ear was calculated from measured data, while the grain weight was determined by weighing two samples of 250 grains that were counted with a numigral seed counter (Chopin SA, Villeneuve-laGarenne, France).

\section{Experimental design and data analysis}

Each trial was set up in a complete randomized block design with nine treatments (wheat varieties) and three replicates. The single plots were $2.25 \mathrm{x}$ $10.0 \mathrm{~m}$.

An analysis of variance including all treatments was performed for each parameter using Proc Mixed of $\mathrm{SAS}^{\circledR}$ (Littell et al., 1996). The single data sets were tested for the requirement of data transformation to guarantee normally distributed residuals. Treatment, environment and treatment $\mathrm{x}$ environment interaction terms were introduced in the linear mixed effects model as fixed effect factors while replication (block), nested within the environment, was defined as a random effect factor. Due to significant interaction terms, data sets were analysed separately for each environment.

The reported results of correlation analyses for the relation of the parameters 


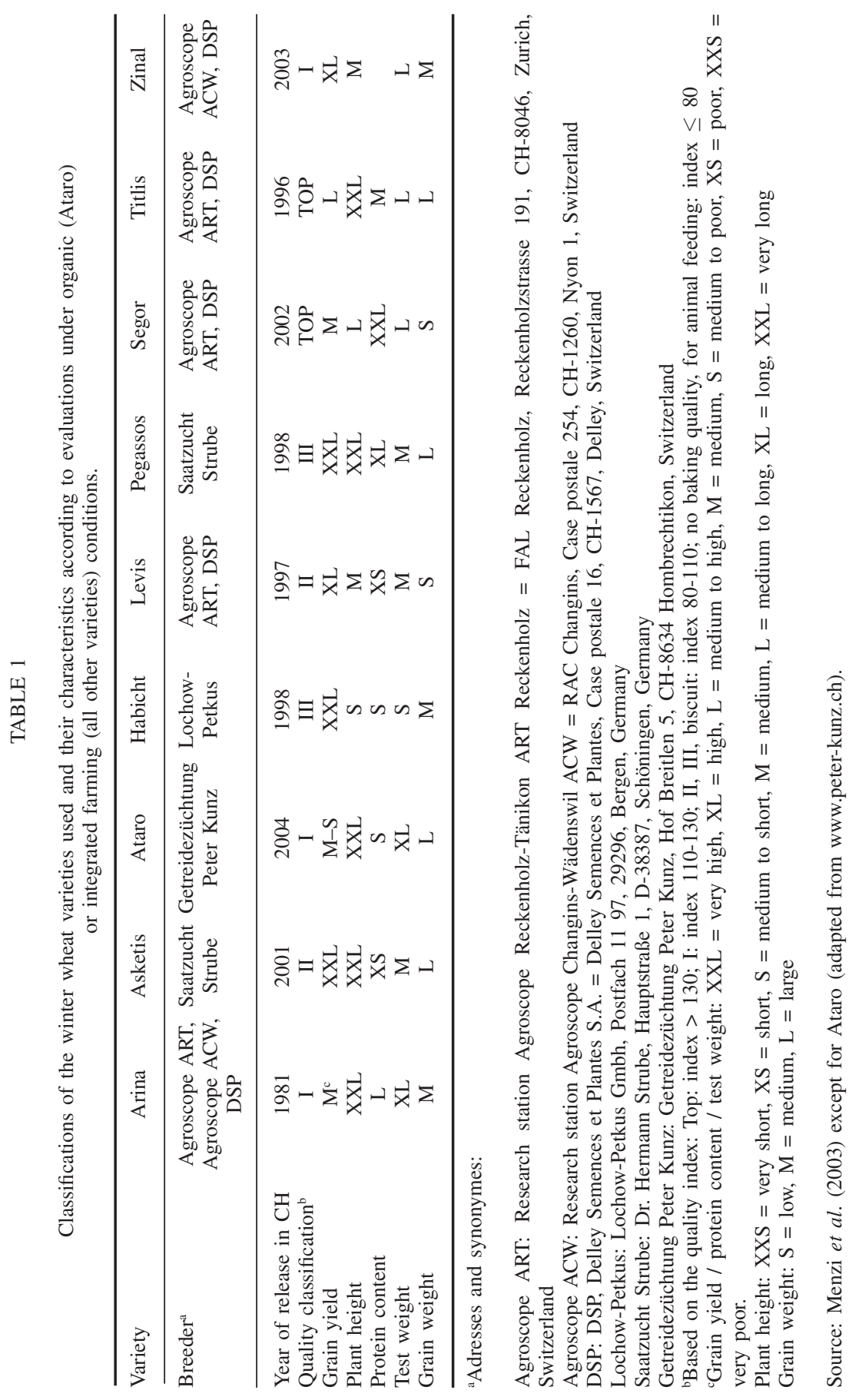


TABLE 2

Overview of the agricultural practices for winter wheat in the three trials,

\begin{tabular}{lcccc}
\hline & $\begin{array}{c}\text { Trial } \\
\text { site }\end{array}$ & $\begin{array}{c}\text { R04 } \\
\text { Reckenholz }\end{array}$ & $\begin{array}{c}\text { S04 } \\
\text { Strickhof }\end{array}$ & $\begin{array}{c}\text { R05 } \\
\text { Reckenholz }\end{array}$ \\
\cline { 2 - 5 } Season & & $2003 / 2004$ & $2003 / 2004$ & 2004/ 2005 \\
\hline Wheat seeding & & $13 \mathrm{Oct}$ & $13 \mathrm{Oct}$ & $14 \mathrm{Oct}$ \\
Mowing in the intra-row: & 1st time & $19 \mathrm{Mar}$ & $19 \mathrm{Mar}$ & $9 \mathrm{Dec}$ \\
& 2nd time & $30 \mathrm{Apr}$ & $14 \mathrm{May}$ & $4 \mathrm{Apr}$ \\
Fertilizing: & $\begin{array}{r}\text { 3rd time } \\
\text { At tillering }\end{array}$ & 19 Jun & $19 \mathrm{Jun}$ & $2 \mathrm{May}$ \\
Wheat harvest & 25 Mar & $18 \mathrm{Mar}$ & $21 \mathrm{Mar}$ \\
& At shoot elongation & $29 \mathrm{Apr}$ & $21 \mathrm{Apr}$ & $13 \mathrm{Apr}$ \\
& & $3 \mathrm{Aug}$ & $3 \mathrm{Aug}$ & $27 \mathrm{Jul}$ \\
\hline
\end{tabular}

within the living mulch system and for the relation of the corresponding parameters of the official Swiss variety testing and the results obtained in this study are based on the Pearson's product-moment correlation calculated with the function cor.test() of R (R Development Core Team, 2005).

\section{RESULTS}

Except for plant density, the analyses of variance showed that all of the studied parameters were influenced by either the wheat variety, the environment or their interaction (Table 4). The ear density was only affected by the environment, whereas the harvest index was basically determined by the wheat variety.

\section{Grain yield}

Grain yields were influenced by the wheat varieties and the environments. Averaged over the environments, Asketis (3.12 $\mathrm{Mg} \mathrm{ha}^{-1}$ ) yielded highest and

TABLE 3

Form of fertilizer and amount of nutrients applied $\left(\mathrm{kg} \mathrm{ha}^{-1}\right)$ in the three trials (R04, S04, R05).

\begin{tabular}{lcccc}
\hline Nutrient & R04 & R04 & \multicolumn{2}{c}{ R05 } \\
\cline { 4 - 5 } & Biorga & $\begin{array}{c}\text { S04 } \\
\text { Manure }\end{array}$ & Compost & Biorga \\
\hline $\mathrm{N}_{\text {available }}$ & 60 & 60 & 35 & 60 \\
$\mathrm{P}_{2} \mathrm{O}_{5}$ & - & 54 & 147 & - \\
$\mathrm{K}_{2} \mathrm{O}$ & 5 & 240 & 230 & 5 \\
$\mathrm{Mg}$ & - & 15 & 1127 & - \\
$\mathrm{Ca}$ & - & 60 & 142 & - \\
\hline
\end{tabular}


Arina (2.18 $\mathrm{Mg} \mathrm{ha}^{-1}$ ) lowest (Table 5). Mean grain yield at R04 (2.20 Mg $\mathrm{ha}^{-1}$ ) and S04 (2.25 Mg ha ${ }^{-1}$ ) reached only 68 and 69\%, respectively, of the value observed at $\mathrm{R} 05\left(3.26 \mathrm{Mg} \mathrm{ha}^{-1}\right)$. Based on pairwise t-tests there were little significant differences among the tested wheat varieties at R04 and S04: at R04 only Titlis $\left(2.25 \mathrm{Mg} \mathrm{ha}^{-1}\right)$ yielded significantly more than Zinal (1.83 $\mathrm{Mg} \mathrm{ha}^{-1}$ ), while at S04 Asketis (2.87 $\mathrm{Mg} \mathrm{ha}^{-1}$ ) yielded significantly more than Arina (1.73 $\mathrm{Mg} \mathrm{ha}^{-1}$ ), Ataro (2.14 $\mathrm{Mg} \mathrm{ha}^{-1}$ ) and Habicht (1.70 $\left.\mathrm{Mg} \mathrm{ha}^{-1}\right)$. At R05 a clearer pattern emerged, with Asketis (4.11 $\mathrm{Mg} \mathrm{ha}^{-1}$ ) and Habicht (4.05 Mg $\mathrm{ha}^{-1}$ ) showing a significantly higher grain yield than all other wheat varieties, except for Pegassos (3.64 $\mathrm{Mg} \mathrm{ha}^{-1}$ ), which was classified as intermediate. Besides the limited statistical distinction of the wheat varieties, their ranking often changed within the three studied environments. For example, the yield of Habicht was among the best at R05 and among the worst at R04 and S04. Nevertheless, some systematic effects can be recognized. Asketis, Titlis and Pegassos were always among the best yielding varieties, while Arina and Zinal were among the lowest yielding varieties.

Grain yield correlated significantly with ear density $(r=0.41 ; p<0.001)$ and plant height $(\mathrm{r}=0.43 ; \mathrm{p}<0.001)$ when calculated over all trials and varieties. With respect to variety, the influence of plant height on grain yield was significant for most varieties, e.g. Asketis $(r=0.94 ; p<0.001)$ and Habicht $(\mathrm{r}=0.80 ; \mathrm{p}<0.01)$. The only exceptions to this general rule are Arina $(\mathrm{r}=0.56 ; \mathrm{p}>0.05)$ and Ataro $(\mathrm{r}=0.57 ; \mathrm{p}>0.05)$.

\section{Plant establishment and densities}

Although the number of established plants varied between 282 (Habicht) and $340 \mathrm{~m}^{-2}$ (Ataro), no significant differences between the varieties were observed (Table 5). Due to the fact that tillering depended on the variety and the environment, the range of values observed for the tiller density was even greater than that of plant density. Interestingly, the extremes were observed for the same variety (Habicht) at different environments: 284 (R04) and $589 \mathrm{~m}^{-2}$ (R05). Tillering was always highest in Asketis and Pegassos. The number of ears did not vary among the varieties (Table 5) and averaged $173 \mathrm{~m}^{-2}$ in R04 and $304 \mathrm{~m}^{-2}$ in S04 and R05.

\section{Plant height and harvest index}

The plant height varied among the trials $(0.80,0.86$ and $0.91 \mathrm{~m}$ at R04, S04 and R05, respectively) and wheat varieties (Tables 5 and 6). For wheat varieties, plant height was the most distinguishable parameter measured; the means are separated into six groups. Arina $(0.96 \mathrm{~m})$ was the tallest variety of 
all and Levis $(0.73 \mathrm{~m})$ the shortest, although it was not significantly different from Habicht $(0.75 \mathrm{~m})$. The other intermediate groups were: Atar and Titlis (0.93 m), Pegassos and Asketis (0.89 m), Segor (0.86) and Zinal (0.77).

The harvest index (HI) only varied among varieties and can be split into four groups: the largest values were observed for Habicht (52.2\%), followed by the second group with a HI between $47.7 \%$ and $49.0 \%$ (Zinal, Levis, Asketis and Pegassos). Ataro, Segor and Titlis form the third group with a HI between $43.1 \%$ and $44.1 \%$, and finally Arina with a $\mathrm{HI}$ of $40.7 \%$.

\section{Yield components}

The grain weight depended on the environment, being significantly higher in R04 (49.0 mg) than in S04 (43.9 mg) and R05 (43.3 mg), and on the wheat varieties. Grain weight was a distinguishing factor for the tested wheat varieties, classifying them in five different categories. Asketis $(50 \mathrm{mg})$ and Pegassos (49 mg) showed the largest and Arina (39 mg) the smallest values (Table 5). There was no association between the grain weight and the grain yield $(\mathrm{r}=0.06 ; \mathrm{p}>0.05)$.

The number of grains per ear was significantly decreased at S04 (16.7) compared with R04 (26.0) and R05 (24.7). Averaged across all trials, Asketis formed the most grains per ear (28) among the wheat varieties. This value was considerably higher than those observed for Arina, Habicht, Zinal, Ataro and Levis, which ranged between 22 and 18. The number of grains per ear significantly influenced the grain yield when averaged over all trials $(r=0.44$; $\mathrm{p}<0.001)$.

\section{TABLE 4}

Analyses of variance for the effects of environment (E), variety (V), and their interaction on grain yield, yield components and quality parameters of winter wheat sown at 450 kernels $\mathrm{m}^{-2}$ into a living mulch of white clover.

\begin{tabular}{lccc}
\hline Parameter & \multicolumn{3}{c}{ p-values } \\
\cline { 2 - 4 } & $\mathrm{E}$ & $\mathrm{V}$ & $\mathrm{E} \times \mathrm{V}$ \\
\hline Plant density & 0.1505 & 0.1665 & 0.3844 \\
Tiller density & 0.0435 & 0.0829 & 0.0183 \\
Tillering coefficient & 0.2420 & 0.0001 & 0.0114 \\
Ear density & 0.0007 & 0.3167 & 0.4555 \\
Plant height & 0.0037 & 0.0001 & 0.0709 \\
Grains per ear & 0.0021 & 0.0238 & 0.8554 \\
Grain yield & 0.0747 & 0.0007 & 0.0156 \\
Harvest index & 0.2619 & 0.0001 & 0.2661 \\
Grain weight & 0.0004 & 0.0001 & 0.0741 \\
Test weight & 0.0005 & 0.0001 & 0.0001 \\
Grain protein & 0.0001 & 0.0001 & 0.0028 \\
\hline
\end{tabular}




\section{Quality parameters}

The grain's protein content varied significantly among the three trials, being highest at R04 (14.0\%), intermediate at S04 (13.0\%) and lowest at R05 $(12.2 \%)$. Among the wheat varieties, Segor always showed the highest protein content in the grain (15.3, 14.6 and $14.2 \%$ at R04, R05 and S04, respectively). Comparable values were found for Arina (at R04 and S04) and Levis (R04). However, Levis was also among those wheat varieties with the lowest protein content in the grain at S04. The wheat varieties Asketis and Pegassos always had the lowest protein content in the grain.

The test weight was higher at R04 $\left(0.833 \mathrm{~kg} \mathrm{l}^{-1}\right)$ and R05 $\left(0.828 \mathrm{~kg} \mathrm{l}^{-1}\right)$ then at S04 $\left(0.810 \mathrm{~kg} \mathrm{l}^{-1}\right)$. Arina, Ataro, Zinal and Titlis were usually the wheat varieties with the highest test weight and were indistinguishable among each other. The wheat varieties with the lowest test weight in all three trials were Asketis and Habicht. Levis, Pegassos, and Segor typically showed intermediate values for the test weight.

\section{Comparison with the conventional variety testing}

Although the plant height in the living mulch system was generally lower than the data obtained in the official variety testing, their correlation was positive and highly significant (Table 6). Similarly, the test weight of the varieties also corresponds well in the different cropping systems. The relationship of the protein content and the grain weight between the two cropping systems was still significant, but the correlation was less distinct than the the plant height and the test weight. Contrastingly, the correlation of the grain yield between the two cropping systems was only significant at R05.

\section{DISCUSSION}

\section{Grain yield}

Grain yields observed for winter wheat in living mulches of white clover in this study (Table 5) were similar or higher to values reported in studies also using a no-tillage seeder at comparable fertilizer levels (White \& Scott, 1991; Bergkvist, 2003b). However, compared with studies with strip-band cultivation for wheat seeding (Jones \& Clements, 1993; Thorsted et al., 2006b), the present yield results were at the lower range of the reported values. In one trial, the yields of the best varieties were even comparable to organic farming systems with ploughing (4100 $\mathrm{kg} \mathrm{ha}^{-1}$, Maeder et al., 2002).

In the tested living mulch system with widely spaced rows of winter wheat, 


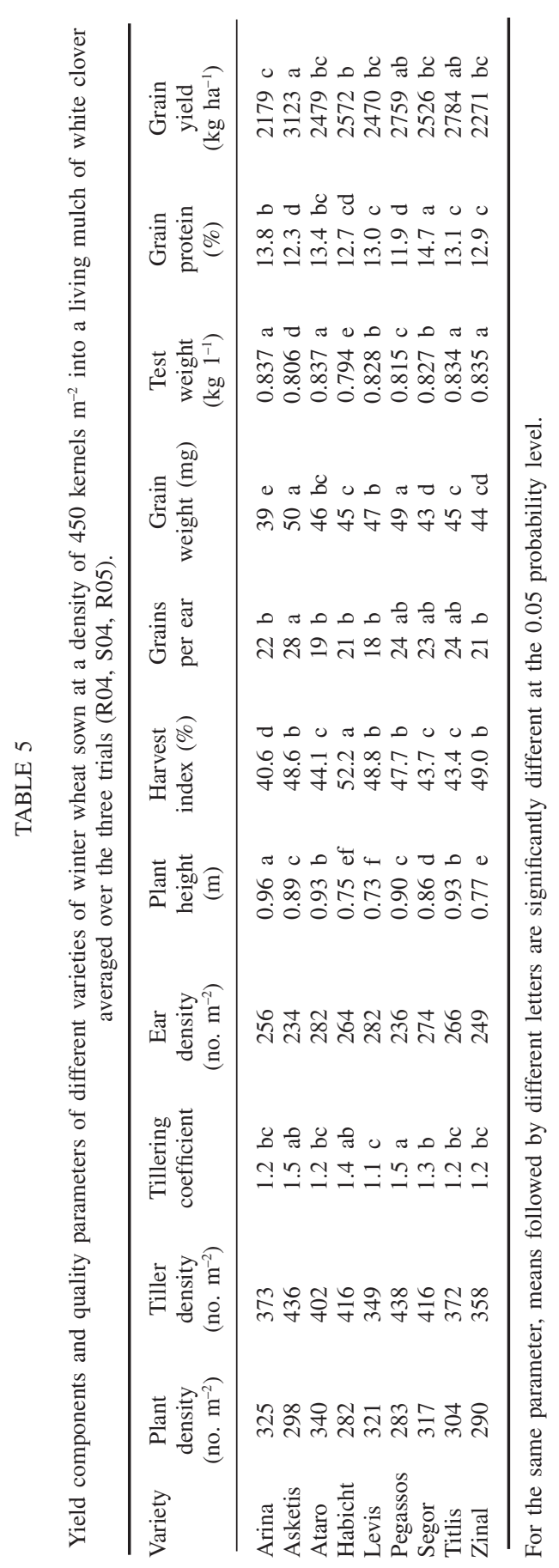


TABLE 6

Correlation coefficients between winter wheat traits measured in the current study and data ${ }^{a}$ of the official variety testing of Switzerland.

\begin{tabular}{|c|c|c|c|c|c|c|c|c|}
\hline \multirow[t]{2}{*}{ Parameter } & \multicolumn{2}{|c|}{ Mean } & \multicolumn{2}{|c|}{ R04 } & \multicolumn{2}{|c|}{ S04 } & \multicolumn{2}{|c|}{ R05 } \\
\hline & $\mathrm{r}$ & p-value & $\mathrm{r}$ & p-value & $\mathrm{r}$ & p-value & $\mathrm{r}$ & $\mathrm{p}$-value \\
\hline Plant height & 0.92 & $* * *$ & 0.95 & $* * *$ & 0.97 & $* * *$ & 0.75 & $*$ \\
\hline Grain weight & 0.70 & $*$ & 0.72 & $*$ & 0.77 & $*$ & 0.56 & ns \\
\hline Test weight & 0.93 & $* * *$ & 0.92 & $* * *$ & 0.85 & $* *$ & 0.63 & $\dagger$ \\
\hline Grain protein & 0.83 & $* *$ & 0.83 & $* *$ & 0.67 & $\dagger$ & 0.77 & $*$ \\
\hline Grain yield & 0.59 & $\dagger$ & -0.01 & ns & 0.29 & ns & 0.70 & $*$ \\
\hline
\end{tabular}

${ }^{\mathrm{a}}$ Mean of available testing environments.

$\dagger, *, * *, * * *$ significant at the $0.1,0.05,0.01,0.001$ probability level, respectively; ns, not significant.

varieties with longer shoots generally yielded higher than varieties with shorter shoots. This can be explained by the stronger shading of the inter-row space, which increased the competitive strength of the crop plants in relation to the white clover crop, resulting in a positive impact on the grain yield. The relevance of long shoots for good yields of winter wheat in living mulches of white clover is substantiated by the positive overall correlation between plant height and grain yield. With respect to variety, only Arina and Ataro did not react this way, which can be explained by their very low harvest index. The positive shading effect that plant height had on white clover is also supported by visual observations during the course of the experiments and was already mentioned by Davis \& Woolley (1993). They argued that taller shoots are a pre-requisite for the achievement of adequate yield levels because it is most likely that such plants will optimally occupy the aerial environment in mixed cropping systems. The importance of light competition in living mulches was also studied by Thorsted et al. (2006b); they showed that competition is strongest at the height of the clover leaves and hence, short genotypes, which have their leaf mass closer to the clover leaves, are affected proportionally more by competition than taller genotypes. However, this condition only holds true when the cover crop in the inter-row space is not kept close to the soil surface by mechanical means. Further investigations of the competitive strength of wheat genotypes with regard to cover crops also need to include the leaf arrangement (erectophil or planophil) and its interaction with plant height.

There is also evidence that the positive effect of plant height on wheat yield in living mulches is more important the higher the competitive pressure exerted by the cover crop: among the environments, correlation between plant height and grain yield was positive and highly significant at R04, but not at R05. This effect was probably brought about by the mowing of the cover crop just prior to the wheat seeding at R05 and at an earlier time in the spring, which 
reduced its biomass at the end of tillering $(\mathrm{BBCH} 29)$ by about $50 \%$ (data sampled in Titlis plots, not shown) when compared with R04, which likely reduced the competition exerted by the white clover on the wheat plants. This pre-sowing damage suffered by the cover crop enabled more light to reach the crop levels close to the soil surface (Thorsted et al., 2006b), which is relevant for a good development and especially for tillering (Vielemeyer \& Weissert, 1990), while also affecting the grain yield (Table 5). Consequently, a significant correlation between the tillering coefficient and grain yield was observed at R04 ( $\mathrm{r}=0.61, \mathrm{p}<0.0001)$ as well as R05 ( $\mathrm{r}=0.63 ; \mathrm{p}<0.001)$. Unfortunately the data from S04 can not be used to support the findings at the other two experimental sites: the low grain yield in S04, which normally would not have been expected based on the ear densities recorded, was due to a hailstorm shortly before the harvest.

\section{Development of the main crop densities}

Plant establishment was low in all trials (66-72\%) and for all tested varieties $(62-76 \%)$ even though the seeding density was adjusted for the germination rate tested for each variety separately. Therefore, some problems must have occurred at or shortly after germination; suboptimal seed bed conditions (Neumann, 2005) caused by the disc of the seeder in the proximity of the seedlings and the occurrence of slugs or diseases are reasons that may have been responsible for the reductions of plant densities. Plant establishment problems in no-tillage and organic farming systems are known (e.g. Sunderman, 1999; Hasler et al., 2000). In order to increase the competitiveness of one of the partners in a mixed crop environment, increasing the seeding density has been proposed for intercropping in general (Davis \& Woolley, 1993) and the benefits on grain yields of winter wheat in living white clover mulches have been reported elsewhere (Hiltbrunner et al., 2007b).

However, increased tillering, as observed for Asketis, Pegassos and Habicht, when compared with most of the other varieties, is no guarantee for an increase in ear density as well (Table 5). The fact that the tillering of these varieties was much higher in R05 than in the others indicates that these varieties could profit more than the others in conditions of reduced light competition caused by mulching in the row prior to seeding.

At harvest, the number of ears was greatly reduced in all varieties. The effect of tiller reduction on ear density was much higher in R04 (53\%) than in S04 (21\%) and R05 (32\%). This may be partly explained by the timing of mowing between the rows of the main crop (to control the cover crop) at R04: it was probably too late for the very competitive white clover causing lack of light for a larger proportion of tillers at R04 than at R05. Although the first spring mowing was carried out on the same date for both S04 and R04, the 
competition exerted by the white clover was lower in S04, mainly due to the later establishment of the living mulch. In addition to the later mowing, the reduced competitiveness of the wheat plants in R04 than in the other trials may also be due to the organic fertilizer source: Liquid farmyard manure with readily available $\mathrm{N}$ was used in S04, while Biorga, a solid and hence slower releasing fertilizer, was applied in the other trials. The later application in R04 than in R05 retarded the availability of $\mathrm{N}$ for the wheat plants in R04 decreasing their competitiveness.

\section{Yield components}

Averaged across all trials and varieties the grain yield was positively and similarly influenced by both the ear density and the number of kernels per ear, while, as was also observed by Bavec et al. (2002), the effect of the grain weight on the grain yield was very weak and not significant. The fact that the ear density was negatively related to the number of kernels per ear and the grain weight, shows that at low ear densities the number of kernels per ear and the grain weight may become more important, which was also shown in other studies conducted in conventional cropping systems (Blue et al., 1990; Bavec et al., 2002). Taking into account the influence of the hailstorm at S04 on the number of kernels per ear and hence considering only trials R04 and $\mathrm{R} 05$, ear density is shown to be more important $(\mathrm{r}=0.62 ; \mathrm{p}<0.0001)$ for the grain yield than the number of kernels per ear $(r=0.30 ; p<0.05)$, which is in agreement with other findings in conventional cropping systems (Bavec et al., 2002).

Except for the negative relation between ear density and grain weight, hardly any other relationship between yield components is significant with respect to variety. This might be explained to some extent by the fact that the grain weight is much more variable across varieties and among environments as well as very little variation within a single variety. The current results suggest that yield components of winter wheat in living mulch systems generally react in a similar way as those reported in studies with conventional systems.

\section{Quality parameters}

The protein content, grain weight and test weight in the three trials varied between the varieties and hence depended mainly on the genetic potential, which agrees with the fact that these parameters are also used to characterize and classify the varieties in the official recommendation of the wheat variety testing (Menzi et al., 2003; Table 1). 


\section{Comparison with the conventional variety testing}

The fact that only grain yield at R05 correlated well with the yield levels under conventional cropping (Table 6) may indicate that the lower the competition from white clover (see above) the better the yield potential of winter wheat under these conditions. Davis \& Woolley (1993) stated that genotype $\mathrm{x}$ cropping system interactions are mainly observed when competition is higher and significant differences among the cultivars' competitive ability exists. Although the competition was generally higher than in systems using ploughing, the differences of the competitive ability of the varieties used in this study were not evaluated in previous experiments.

The negative response of protein content to an increased grain yield was more pronounced in varieties already classified as inferior (III) $(\mathrm{r}=-0.61$; $\mathrm{p}<0.01$ ) than in superior varieties (TOP, $r=-0.49$; $\mathrm{p}=0.053$ ). Furthermore, Kramer (1979) showed that at a given environment a negative correlation exists between the grain yield and the protein content, which is attributed to genetic differences. The significant interaction of variety $\mathrm{x}$ environment for the protein content (Table 4) indicates that varieties do not react identical at different environmental conditions and is in agreement with Kramer's statement (1979), which mentions the diverse response of the grain protein of different genotypes depending on the environment.

Asketis, Pegassos and Habicht, which are grouped in classes II or III (Table 1) and consist of varieties with lower quality and higher yield level, generally yielded highest in the living mulch systems. This shows that varieties that are selected in conventional cropping systems to produce a higher grain yield with a lower quality are better adapted to conditions of stronger plant competition. Since biomass and yield are typically closely correlated and biomass is an indicator of competitive strength, it can be assumed that varieties of these classes are better suited to compete with a living cover crop. However, it is the tillering coefficient and not the ear density that distinguished these varieties from the others. Therefore, it is hypothesized that besides the importance of the ear density for grain yield formation as discussed above, tiller formation is also an important characteristic for wheat varieties cultivated in a living mulch system under the stated management conditions.

\section{CONCLUSIONS}

Among the best yielding wheat varities in the living mulch system (Asketis, Titlis, Pegassos and Habicht) three were from the two lowest grain quality classes (II and III). These three varieties profited from a higher tillering intensity. In addition Asketis and Pegassos were among those with a long shoot, an indication of a strong shading and, thus, suppression of the cover 
crop. However, this explanation does not apply to Habicht, the second shortest genotype. Hence, in order to enable satisfying yields of high quality wheat in living mulch systems, competition with the clover needs to be reduced more than with low quality and high yielding varieties which are suited better to the living mulch system with white clover.

When the competition between the winter wheat crop and the white clover living mulch is strong, the yield performance of the wheat varieties does not reflect the official recommendation elaborated from field trials conducted under conventional conditions, probably because of the negative effect of the interspecific competition on the ear density. However, when the crop management allows for a reasonable competitive advantage of the wheat plants, yield performance of winter wheat varieties sown in a living mulch of white clover closely reflect the results from conventional cropping. Contrastingly, when grain quality is the main goal, the official recommendation is a reliable guideline for choosing winter wheat varieties for cultivation in white clover living mulches.

\section{ACKNOWLEDGEMENTS}

The authors would like to thank F. Gut, C. Humphrys, F. Käser, H.-H. Rast and E. Uhlmann for their support in the field and M. Menzi and M. Anders for providing data from the official variety testing experiments. D. Nobert is acknowledged for proof-reading the manuscript.

\section{References}

Bavec, M., Bavec, F., Varga, B. \& Kovacevic, V. (2002). Relationships among yield, it's quality and yield components, in winter wheat (Triticum aestivum L.) cultivars affected by seeding rates. Bodenkultur, 53, 143-151.

Bergkvist, G. (2003a). Influence of white clover traits on biomass and yield in winter wheat- or winter oilseed rape-clover intercrops. Biological Agriculture \& Horticulture, 21, 151-164.

Bergkvist, G. (2003b). Effect of white clover and nitrogen availability on the grain yield of winter wheat in a three-season intercropping system. Acta Agriculturae Scandinavica Section B-Soil and Plant Science, 53, 97-109.

Bio Suisse (2005). Richtlinien für die Erzeugung, Verarbeitung und den Handel von KnospeProdukten. Fassung vom 1. Januar 2005, Bio Suisse; Basel, Switzerland.

Blue, E.N., Mason, S.C. \& Sander, D.H. (1990). Influence of planting date, seeding rate, and phosphorus rate on wheat yield. Agronomy Journal, 82, 762-768.

Brandsæter, L.O., Netland, J. \& Meadow., R. (1998). Yields, weeds, pests and soil nitrogen in a white cabbage living mulch system. Biological Agriculture \& Horticulture, 16, 291-309.

Davis, J.H.C. \& Woolley, J.N. (1993). Genotypic requirement for intercropping. Field Crops Research, 34, 407-430

Feil, B. \& Liedgens, M. (2001). Crop production in living mulches - a review (in German, with English abstract). Pflanzenbauwissenschaften, 5, 15-23.

Friend, D.J.C. (1965). Tillering and leaf production in wheat as affected by temperature and light intensity. Canadian Journal of Botany, 43, 1063-1076. 
Hartwig, N.L. \& Ammon, H.U. (2002). 50th Anniversary - Invited article - Cover crops and living mulches. Weed Science, 50, 688-699.

Hasler, M., Keller, L. \& Meyer, A. (2000). Datenblätter Ackerbau (in German). LBL Landwirtschaftliche Beratungszentrale; Lindau, Switzerland.

Hiltbrunner, J., Liedgens, M., Bloch, L., Stamp, P. \& Streit, B. (2007a). Legume cover crops as living mulches for winter wheat: Components of biomass and the control of weeds. European Journal of Agronomy, 26, 21-29.

Hiltbrunner, J., Streit, B. \& Liedgens, M. (2007b). Are seeding densities an opportunity to increase grain yield of winter wheat in a living mulch of white clover? Field Crops Research, 102, 163-171.

Jones, L. \& Clements, R.O. (1993). Development of a low-input system for growing wheat (Triticum vulgare) in a permanent understorey of white clover (Trifolium repens). Annals of Applied Biology, 123, 109-119.

Kramer, T. (1979). Environmental and genetic variation for protein content in winter wheat (Triticum aestivum L.). Euphytica, 28, 209-218.

Lancashire, P., Bleiholder, H., Langelüddecke, P., Stauss, R., van den Boom, T., Weber, E. \& Witzenberger, A. (1991). An uniform decimal code for growth stages of crops and weeds. Annals of Applied Biology, 119, 561-601.

Littell, R., Milliken, G., Stroup, W. \& Wolfinger, R. (1996). SAS® System for Mixed Models. SAS Inst; Cary, NC, U S A.

Maeder, P., Fliessbach, A., Dubois, D., Gunst, L., Fried, P. \& Niggli, U. (2002). Soil fertility and biodiversity in organic farming. Science, 296, 1694-1697.

Menzi, M., Anders, M., Collaud, J.-F., Schwärzel, R. \& Bertossa, M. (2003). Von der Branchenorganisation empfohlene Getreidesorten für die Ernte 2004. Inclosure Agrarforschung 10 (7).

Neumann, H. (2005). Optimierungsstrategien für den Getreideanbau im ökologischen Landbau: System "weite Reihe" und Direktsaat in ausdauernden Weissklee ("Bi-cropping"). Schriftenreihe des Instituts für Pflanzenbau und Pflanzenzüchtung der Christian-Albrechts-Universität zu Kiel 43. Dissertationsschrift, Universität Kiel, Germany.

R Development Core Team (2005). R: A Language and Environment for Statistical Computing. R Foundation for Statistical Computing; Vienna, Austria.

Sunderman, H.D. (1999). Response of hard red winter wheat to seed density and seeding rate in no-till. Journal of Production Agriculture, 12, 100-104.

Thorsted, M.D., Olesen, J.E. \& Weiner, J. (2006a). Mechanical control of clover improves nitrogen supply and growth of wheat in winter wheat/white clover intercropping. European Journal of Agronomy, 24, 149-155.

Thorsted, M.D., Olesen, J.E. \& Weiner, J. (2006b). Width of clover strips and wheat rows influence grain yield in winter wheat/white clover intercropping. Field Crops Research, 95, 280-290.

Vielemeyer, H.P. \& Weissert, P. (1990). Studies into the influence of light, temperature, soilmoisture and nitrogen on tiller development in winter wheat. Archives of Agronomy and Soil Science, 34, 461-467.

White, J.G. \& Scott, T.W. (1991). Effects of perennial forage-legume living mulches on no-till winter wheat and rye. Field Crops Research, 28, 135-148.

(Received 23 March 2007; accepted 24 April 2008) 
